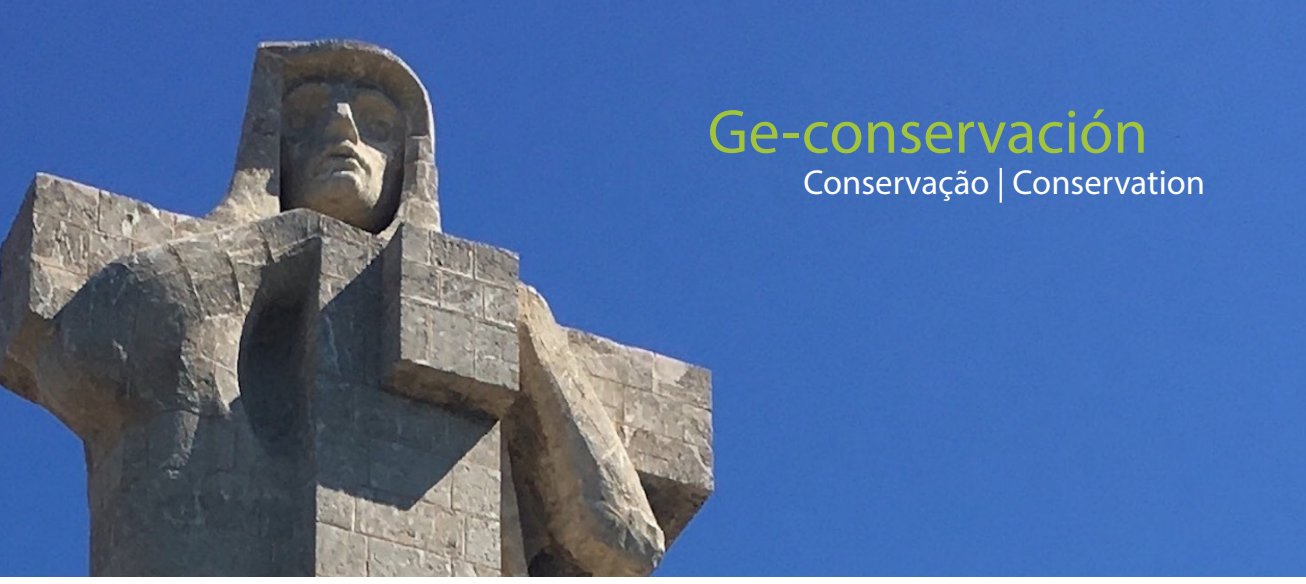

\title{
Estudio crítico sobre la actual destrucción política del monumento urbano
}

\author{
Fernando R. Contreras
}

Resumen: Este estudio se ha centrado en el conflicto actual de la ciudadanía con los monumentos públicos como muestran varios sucesos de ataques vandálicos aparecidos en los medios de comunicación. Desde la hipótesis de una representación artístico-histórica fallida al eludir la realidad del contexto político y las reacciones emocionales de determinados movimientos sociales, presentamos un estudio crítico articulado entre los estudios visuales, la política y la filosofía del arte. Entre las conclusiones más relevantes, destacamos la crisis del valor simbólico de las narrativas que representan estas imágenes del pasado, las violentas reacciones de movimientos sociales que denuncian la ocupación del espacio público cuando la mirada de espectador sobre el objeto genera opinión pública y la oposición popular en el vandalismo frente a la inexistencia de un programa iconoclasta institucional que revise la resignificación de los monumentos en los tiempos presentes.

Palabras clave: monumentos, ciudad, política, iconoclasia, vandalismo, movimientos sociales

\section{Critical study on the current political destruction of the urban monument}

Abstract: This study has focused on the current conflict of citizens with public monuments as shown by several events of vandalism attacks reported in the media. Based on the hypothesis of a failed artistic-historical representation that eludes the reality of the political context and the emotional reactions of certain social movements, we present a critical study articulated between visual studies, politics, and the philosophy of art. Among the most relevant conclusions, we highlight the crisis of the symbolic value of the narratives that represent these images of the past, the violent reactions of social movements that denounce the occupation of public space when the spectator's gaze on the object generates public opinion and the popular opposition in vandalism in the face of the non-existence of an institutional iconoclastic programme that revises the resignification of monuments in the present times.

Keywords: monuments, city, politics, iconoclasm, vandalism, social movements

\section{Estudo crítico sobre a atual destruição política do monumento urbano}

Resumo: Este estudo concentrou-se no conflito atual da cidadania com os monumentos públicos como mostram vários eventos de ataques de vandalismo nos meios de comunicação. Desde a hipótese de uma representação artístico-histórica fracassada ao eludir a realidade do contexto político e as reações emocionais de determinados movimentos sociais, apresentamos um estudo crítico articulado entre os estudos visuais, política e filosofia da arte. Entre as conclusões mais relevantes, destacamos a crise do valor simbólico das narrativas que representam estas imagens do passado, as violentas reações de movimentos sociais que denunciam a ocupação do espaço público quando o olhar de espectador sobre o objeto gera opinião pública e a oposição popular no vandalismo frente à inexistência de um programa iconoclasta institucional que reveja a resignificação dos monumentos nos tempos presentes.

Palavras-chave: monumentos, cidade, política; iconoclasia, vandalismo, movimentos sociais 


\section{Introducción: ver ya no es creer}

Al recorrer los escritos metodológicos sobre el monumento moderno encontramos al historiador Riegl (2008 [1903]: 23) que ofrece una definición y una refutación, sin que luego haya habido gran cosa que agregar: "una obra realizada por la mano humana y creada con el fin específico de mantener hazañas o destinos individuales (o conjunto de éstos) siempre vivos y presentes en la conciencia de las generaciones venideras". El estudio de Riegl muestra lo remoto de la genealogía de los monumentos, cuyas intenciones en la actualidad se cuestionan por el cambio de actitud y comportamiento de la ciudadanía frente a ellos.

El monumento reclama un valor artístico y un valor histórico de las actividades humanas y de los albures de la humanidad. El monumento rememora períodos destacados y se expresa por medio de distintas formas artísticas: desde la escritura (la lectura comunica las ideas contenidas en la conciencia) a las artes plásticas (las obras percibidas por la vista y el tacto). El arte que encontramos en el monumento será en primera instancia, como dice Riegl, un valor histórico-artístico. Es normal encontrar numerosos monumentos que repiten su contenido con detalles artísticos diferentes. Es el caso de los monumentos erigidos a la figura histórica de Cristóbal Colón (Hernández-Mora 2021) en los que también es evidente otro valor de carácter rememorativo: la conmemoración del descubrimiento del continente americano. Este valor rememorativo puede ser intencionado, es decir, provocado por la mano del artista, pero también lo puede esgrimir una obra que solo manifieste huellas del pasado (Manetto y Marcial Pérez 2021).

Continuando con el estudio de Riegl, que nos permite plantear el estado de la cuestión, los monumentos ofrecen también un sustrato anímico que no solo afecta al individuo en cuanto ser efímero en el mundo, sino que también satisface los sentimientos de las masas (sentimientos religiosos o ideológicos). Los monumentos aportan esa dimensión espiritual a través de la semiótica visual ligada a su interpretación. Unas ruinas recuerdan la grandeza del pasado de una civilización y la degradación que ésta sufre en el presente. Las huellas visuales del pasado también estremecen cuando testimonian períodos de esclavitud, de invasiones, de violentas conquistas imperiales, $y$, en pocas palabras, de inhumanidades.

Los monumentos poseen dos valores en tensión como son la antigüedad, que posee la ambición universal de dirigirse a todos (un público cultivado o las masas) desde la conservación de un pasado común, y un valor instrumental, cuando su función se adecua a la circulación y manipulación humana, es decir, cuando volvemos a reactivar el monumento con una función diferente, de acuerdo con la evolución del pensamiento y el comportamiento humano de nuevos tiempos.

Recientes noticias publicadas por los medios de comunicación informan sobre ataques vandálicos a los monumentos en distintos lugares del mundo, o sobre decisiones oficiales por parte de instituciones gubernamentales de su retirada de espacios públicos. Este malestar ciudadano con el patrimonio urbano ha sido la causa de recientes manifestaciones por todo el mundo. Por citar algunas evidencias que aparecen publicadas en los medios (Agencias 2020): 1) Estatua de Cristóbal Colón, Boston, 9 de junio 2020. La imagen es decapitada. Navegante genovés (1451-1506); 2) Estatua de Jefferson Davis, Richmond, Virginia, 10 de junio 2020. La imagen es derribada. Héroe confederado (1808-1889) que defendía el sistema esclavista. Estas evidencias muestran el monumento como una realidad poliédrica en la que la política y la visualidad se solapan en un palimpsesto de nueva textualidad social.

Este trabajo establece el supuesto (la hipótesis) que la destrucción actual del monumento deriva de su integración en un particular régimen escópico que fusiona lo representativo, lo político y lo estético. En esta fusión, las imágenes dan testimonio de un mundo autónomo de sus cualidades visuales y de su poder para construir la comunidad. Por este motivo, las obras monumentales son cuestionadas por su verdad y por su efecto en la ética de los individuos y de la comunidad. Los monumentos son obras que ofrecen una forma política a la realidad mediante la materia, y, en la actualidad, bajo el consenso y la acción disidente, entran en un ciclo de muertes y renacimientos. La formación estética de un mundo colectivo supone para el monumento un ciclo de designificación y resignificación con los valores políticos vigentes que al final termina en la composición de la nueva trama de nuestra historia cultural.

\section{Los motivos de la destrucción visual: la guerra política de las imágenes}

Su emplazamiento privilegiado crea una esfera pública al administrarles una dirección o un destino. Los monumentos no representan de modo directo el poder, no les es necesario. La iconofilia a estas imágenes exige a priori la existencia de un ritual público en el que se muestra la lealtad de los correligionarios. Para que los monumentos sean el objetivo de ataques, las imágenes tenían primero que estar allí, para que después, atrajesen hacia sí las formas de adoración. La moralidad obligada de un régimen requería una dirección y una imagen destinada a ello. Antes de que una imagen fuese objetivo de iconoclastas, era un objeto de veneración de idólatras. Es decir, "la iconoclastia era el culto a las imágenes de signo invertido" (Belting 2012: 93). La consagración de las imágenes también sobrevivirá en las sociedades secularizadas; es el residuo ideológico que permanece en una comunidad que practicaba religión o creencia.

De la crisis de los monumentos es, en parte, responsable la crisis del poder, de la figura representante y de su autoridad (que ya no protege su imagen). Coincidiendo con la totalidad de la posmodernidad, la obra 
monumental participa de la crisis de sentido que ha causado la inestabilidad de las Instituciones, Academias y de los grandes metarrelatos de la modernidad (Connor, 2002). Una crisis de sentido que ocasiona la inflación de discursos aceptados y su continua renovación nihilista y deconstructiva. La Iglesia, la Democracia, el Estado, el Arte, los responsables de los principios directivos o de las mitologías universales que controlaban o delimitaban las formas discursivas en el mundo caen bajo sospecha. La multiplicación de los centros de poder que controlan la actividad de la representación social, la decadencia de la autoridad cultural de Occidente y sus tradiciones políticas e intelectuales junto con la apertura de la escena política mundial a las diferencias étnicas y culturales generan, en la opinión de algunos, el paso de la jerarquía a la anarquía (Connor 2002: 23).

Esta atmósfera resulta mucho más fenomenológica que iconológica en el sentido, al menos, habitual del historiador Erwin Panofsky (2004 [1962]). El influjo de estas imágenes no repercute sobre el contenido de la interpretación, sino sobre una invocación a la interpretación. El monumento no sugiere que hay algo más que la representación y la reificación del mundo sensible (espacios públicos construidos, figuras humanas o verosimilitudes narrativas). Tras la figuración monumental se oculta un rasgo inesperado, algo no sometido a su referencialidad, una trama subjetiva generada por la mente colectiva y política de la comunidad.

La reacción popular contra los monumentos se organizó en el pasado alrededor de religiones que atravesaban desde Bizancio a Damasco. En la actualidad, esta situación no ha cambiado tanto. Las religiones pueden ser la doctrina alrededor de la cual se organiza los actos iconoclastas, pues salvo los casos particulares de individuos perturbados, detrás del rito de la destrucción de imágenes siempre aparece una doctrina que mezcla teología con política (Watney 2015).

Los asaltos a monumentos no tienen las mismas implicaciones teóricas y estéticas que los acaecidos por una moralidad del pasado. La recurrencia a la censura de las imágenes efervescentes consideradas de mal gusto por su realismo sexual, el pudor, o en última instancia, la veracidad reflejada en la desnudez de las formas, ya no es el único motivo de una iconoclasia institucional. No obstante, Freedberg (2009) confirma la importancia de las respuestas emocionales y viscerales a las imágenes y al arte a lo largo del devenir histórico. Sin duda, la iconoclasia acaba marcando en el tiempo episodios históricos, como la eliminación iconográfica realizada por las concentraciones populares de los "Leninoclastas" de 1989 en Moscú y en todo el territorio del bloque oriental (Scotini 2009: 2). Los cambios de regímenes políticos han ido acompañados de la desfiguración, desplazamiento o destrucción de las obras exhibidas frente la mirada de los subversivos. Es una de las conclusiones a las que llegaba el estudio de Gamboni (1997) sobre la iconoclasia desde la Revolución Francesa. También los actos iconoclastas contemporáneos surgen de un entorno revolucionario instigado por el activismo político de los años sesenta. Un ejemplo de ese espíritu reivindicativo lo encontramos en las protestas del movimiento Black Lives Matter contra la discriminación racial que inspiró a nivel global una serie de ataques contra monumentos que constituían símbolos de opresión (Redacción y agencias 2020).

Las imágenes por sí mismas son dialécticas por la tensión que contienen entre lo psíquico y lo objetivo, la violencia dionisíaca y la belleza apolínea. Noguera Gracia revela esta implicación en el malestar con el monumento: "Tras los actos de iconoclasia hay un contenido simbólico, una intención política y una narrativa que respalda y justifica la acción" (Noguera Gracia 2018: 10). Para Stollbrock Trujillo (2017), la iconoclasia es consecuencia del realismo en la representación del mundo, entendiendo el realismo como un discurso sobre la verdad. De modo que lo representado impide la memoria de lo no representado, además de evitar la narración del pasado. Esta paradoja "inmemorial" que se basa en la prohibición de imágenes (Bildverbot) motivó que el cristianismo primitivo prohibiera en sus comienzos las imágenes, pues una imagen de Dios en un lugar sagrado expresaba en concreto su ausencia: la representación material testimoniaba solo las particularidades de su referente indicial. Más tarde, fue la doctrina de la encarnación la que justificó en el cristianismo la utilización de las imágenes. Después de todo, Dios se había reencarnado en la figura material de Cristo, por lo que la realización de una figura tallada podría interpretarse como hacer una cosa viva. Para Freedberg (2017) esta justificación cierra la reciprocidad entre figuración e idolatría.

Los movimientos sociales se centran con cierta preferencia en las dimensiones políticas de la visibilidad pública de los monumentos que impactan sobre la opinión pública. Algunos ejemplos son: 1) el movimiento feminista \#NoMeCuidanMeViolan en México durante su manifestación del 12 de agosto del 2019 cubrió la Columna del Ángel de la Independencia con frases como "México feminicida" y "No se va a caer, lo vamos a tirar" (Pérez-Ramos y Ramiro-Esteban 2020); 2) la marcha del 18 de octubre de 2019 en la Plaza Italia, localizada en Santiago de Chile, acabó en actos vandálicos y la sede de la Universidad Pedro de Valdivia, un edificio patrimonial fechado en c. 1915, fue incendiada; 3) el movimiento \#Black Lives Matter provocó la demolición de estatuas en Estados Unidos, Reino Unido y tuvo resonancia en otros lugares del mundo; 4) el movimiento Rhodes Must Fall nació el 9 de marzo de 2015 contra la estatua de Cecil Rhodes en la Universidad de Ciudad de Cabo y se extendió por Sudáfrica, Estados Unidos y Reino Unido.

El texto sobre política de la iconoclasia de Noyes demuestra que en 1530 la denuncia de Calvino de las imágenes de la Iglesia cristiana fue una estrategia política para el desarrollo de la sociedad civil de Ginebra: "En la 
actualidad, por toda la ciudad hay placas que celebran la forma en que trabajaron en paralelo la destrucción de imágenes y la democracia racionalista" (Noyes 2018: 102). El estudio de Strother (2002) muestra el funcionamiento de la iconoclasia en los procesos de colonización y descolonización (Hernandez 2019), en los que los actos de mutilación, difamación, retirada o destrucción de las imágenes adquirió una dimensión positiva en la política.

La iconoclasia es en la modernidad una estrategia política que utiliza el nuevo poder institucional para controlar el régimen escópico de una comunidad. Después del golpe de estado en Argentina que derroca al presidente Perón en 1955, se llevó adelante un proceso de destrucción de imágenes, símbolos e insignias relativos al movimiento que será instituido al poco tiempo con "el decreto ley 4161 de marzo de 1956 que prohibía expresamente en su artículo 1 "la utilización de imágenes, símbolos, signos, expresiones significativas, doctrinas, artículos y obras artísticas, (...) que sean (...) representativas del peronismo" (Soneira 2020: 12). También hubo una resignificación visual de símbolos y retirada de monumentos durante la Revolución Bolivariana o "Revolución Bonita" (1999) en la República Bolivariana de Venezuela (Contreras y Ramírez 2021). El comandante supremo, Hugo Rafael Chávez Frías, decretó el 12 de octubre como "Día de la Resistencia Indígena" (N²028) en sustitución del “Día de la Raza”. Dos años después grupos vandálicos derribaron la estatua de Colón en la céntrica Plaza Venezuela de la capital y luego tras un juicio simbólico, la colgaron (García Marco 2016). Los ejemplos se repiten en períodos históricos concretos en los que hay un cambio de régimen político.

El principal precedente de estos hechos, sin duda, es la iconoclasia bizantina (Mondzain 1996). La teología y la política se entrecruzaban para respaldar el poder imperial. Los debates cristocéntricos, si bien giraban alrededor de la imposibilidad del arte de representar la naturaleza de Cristo, pronto tornaron en debates políticos. Freedberg (2017) descubre que los argumentos teológicos sobre las imágenes fueron considerados modelos para los razonamientos habituales, incluyendo los políticos y psicológicos. Los modelos funcionaban, según nuestro autor, debido a la relevancia del sentido de la encarnación. Así era que la imagen del emperador romano debía tratarse como si fuese el propio emperador: "En las antiguas concepciones romanas, emperadores y reyes estaban donde estaban sus imágenes" (Freedberg 2017: 41). El homenaje a la persona podía brindarse a través del homenaje a su imagen, y viceversa, se podía agredir a la figura poderosa atacando a su imagen. En la actualidad, la frustración popular contra los poderes opresores (tiranos, ideologías o cosmovisiones hegemónicas) se manifiesta en la protesta pública que carga con ferocidad sobre sus representaciones más fáciles de derrocar que al propio sujeto de la represión. En estas disputas iconoclastas, la obra monumental no solo juega con factores políticos, sino que éstos se ven entrecruzados por razones históricas (colonización/descolonización), teológicas (choque entre culturas y creencias diferentes) y psicológicas (rechazo de identidades).

\section{Iconoclasia versus vandalismo: otra mirada crítica so- bre el culto del monumento}

En la actualidad, la iconoclasia perdura con forma de vandalismo, salvo excepciones institucionales, cuya doctrina ideológica otorga oficialidad a un plan de eliminación o retirada de imágenes. La propuesta de resolución común sobre la importancia de la memoria histórica europea para el futuro de Europa (2019/2819(RSP), aconsejaba a las naciones europeas la eliminación de las imágenes fascistas o comunistas. En España, la "Ley de Memoria Histórica 52/2007, de 26 de diciembre por la que se reconocen y amplían derechos y se establecen medidas en favor de quienes padecieron persecución o violencia durante la Guerra Civil y la Dictadura" obliga a instituciones y entidades privadas a la eliminación o retirada de los espacios públicos de imágenes, monumentos, insignias, símbolos o placas de calles del régimen dictatorial franquista. Otras leyes en otros países siguen la misma dirección. En Estados Unidos (Gaddie y Evans 2021), hubo una remoción de monumentos confederados desde los años sesenta que se vio impulsado por incidentes raciales como el tiroteo en la iglesia de Charleston (Faus, 2015), la manifestación Unite the Right con la retirada de la estatua de Robert Edward Lee en Charlottesville (Faus y De Llano 2017) y el asesinato del ciudadano negro George Floyd en un acto de violencia policial (Ros 2020).

El concepto de monumento contemporáneo surge a partir de los años sesenta, y encuentra una buena fundamentación en el manifiesto publicado en 1943 por Sigfried Giedion, Josep Lluís Sert y Fernand Léger titulado "Nueve puntos sobre monumentalidad" (Sert, Léger y Giedion 2015) que produce el cambio drástico del reemplazo de la obra conmemorativa, ideológica, política y simbólica por la obra artística de vanguardia (p.e. "El peine del viento", en la ciudad española de San Sebastián, de Eduardo Chillida 1977). Así, el ritual vandálico ha quedado limitado a un acto de purificación de los lugares públicos donde el monumento es un anacronismo visual que todavía concede a la imagen la esencia que contuvieron en el pasado (Bellentani y Panico 2016). Una esencia, que como afirmábamos antes, en la actualidad solo la posee la obra de arte: "Los monumentos son expresión de las más altas necesidades culturales del hombre. Están destinados a satisfacer el ansia eterna del pueblo por traducir en símbolos su fuerza colectiva. Los monumentos vivientes son los que dan expresión a esa fuerza colectiva" (Sert, Léger y Giedion 2015: 7). Frente al malestar político, conflictos e inquietudes sociales que supone el culto a la visualidad del monumento, la contemplación pública ha sido reducida a la obra de arte. En consecuencia, en esos espacios abiertos a todas las miradas, museos y plazas públicas, el monumento ha sido reemplazado en muchas ocasiones por las "obras plásticas". 
El monumento produce su propia política, reconfigura el espacio urbano como un asunto político. En consecuencia, adquiere la autonomía de la experiencia y participa, como forma de vida, en un plan de autoformación. El monumento, en calidad de obra de arte, supone la formación del ciudadano en un régimen estético concreto. Es en ese proceso de educación estética cuando el monumento llega a un acuerdo con el régimen ético. Tal es el punto de vista que interroga el Memorial "Ground Zero" en recuerdo de las víctimas del atentado terrorista 11-S, del 2001 en la ciudad de New York.

El redescubrimiento de la "comunidad", la constitución actual de un tercer sector no estatal, ni lucrativo (mercado) que activa redes ciudadanas y movimientos sociales ha invertido el sentido de la iconoclasia. El nexo asociativo entre estos movimientos ciudadanos y la iconoclasia es el rechazo a la glorificación de ciertos personajes o ideologías que arrastran problemas de "empatía" con la comunidad. Es una cuestión de dolor psíquico. En esta dirección, Lai (2020) publica una defensa del vandalismo cuando el ataque se dirigea"símbolos políticos contaminados" que permanecen por la pasividad de las actuaciones oficiales. Para Lai, la desfiguración, destrucción o remoción no autorizada de símbolos políticos puede ser un acto moral permisible o incluso obligatoria en ausencia de un programa iconoclasta institucional. Lim (2020) también coincide en la función política del vandalismo resignificando el monumento de homenaje público en un acto de repudio o de humillación pública. Reconoce el potencial transformador del vandalismo y su acción organizada por los activistas progresistas en los últimos años. También es interesante la perspectiva de Miranda (2020) que pretende encontrar en la iconoclasia las huellas críticas de la mirada nietzscheana sobre los monumentos. Para Miranda, la iconoclasia es una alternativa particular de juzgar y rechazar la veneración y adoración de personajes históricos, y que finaliza en la descolonización del espacio público. Así también lo sugieren Pérez-Ramos y Ramiro-Esteban (2020: 46-47) cuando afirman que "el patrimonio cultural es un recurso de cohesión social, que puede ser aprovechado en algunas sociedades como herramienta política, de reivindicación social y como elemento de lucha, y que es utilizado para construir y resignificar identidades". Además reconocen que su destrucción reinventa las consignas del monumento histórico.

El vandalismo no actúa solo sobre la dimensión estética de arte (Réau 1994), más que una lectura artística, el malestar sentido a la vista tiene que ver con su función textual conmemorativa o representativa de la historia que el poder institucional reconoce como "memoria". Además, como suscitan Trachana y Şerbănoiu (2020) en su estudio, cuando tratamos con lugares de la memoria cabe varias matizaciones conceptuales y formales que diferencian a un monumento ( $y$ a la cualidad de monumentalidad de una obra), los memoriales y los museos: "El memorial encarna el dolor, la pérdida y el tributo o la obligación; al hacerlo, sirve para enmarcar narrativas históricas particulares. (...) En su lectura formal se privilegia su función textual conmemorativa" (Sturken 1991: 120-121, citado en Trachana y Şerbănoiu 2020: 608).

Para Marschall (2017: 674), el vandalismo es una reacción contraria a la regulación racional del Estado sobre la sociedad y sus espacios cotidianos imponiendo planes y programas en el ámbito público y privado. Cuando esta oposición se manifiesta con la desfiguración del monumento se le acusa de acto irracional, violento y bárbaro. Sin embargo, la humillación sobreentendida en el desgarre provocado por la obra monumental puede traducirse en un gesto de desobediencia civil que rechaza el silencio al que las instituciones obligan, en ocasiones, a la ciudadanía. Esta violencia simbólica es consecuencia de diferentes concepciones del simbolismo del "espacio vacío". La ocupación de estos lugares por organizaciones a favor de la instalación de objetos conmemorativos, calificados de símbolos relevantes para la instrumentalización moral del legado cultural no siempre es bien aceptada por motivos diferentes de carácter ideológico, por su contenido y significado, su forma física y estilo, e incluso por razones territoriales cuando el monumento afecta a la libertad de movimiento, la oportunidad de reunión o al comportamiento de la ciudadanía.

\section{A modo de conclusión}

Por último, reconocemos que los monumentos se sumergen en una visión nutrida de valores actuales que les conceden enseguida una dimensión nueva. Sus significaciones se convierten en la matriz de un programa político para el ciudadano disidente que no coincide con las afirmaciones de sus gobernantes e instituciones. Su ubicación pública le otorga al monumento una extraordinaria circunstancia para intervenir en el diálogo entre política y derecho, dirimiendo sobre diferencias. El monumento no solo interviene en la construcción de la opinión pública, sino que también su visibilidad aporta certeza impulsora de transformaciones en la intimidad del ser humano, iluminando su inteligencia o modelando su comportamiento ético.

La inclusión social sirve de justificación para la destrucción del monumento, considerada ahora dicha acción destructiva como estratégica para la renovación política y para la reordenación de movimientos sociales. Las reinterpretaciones de los monumentos, en razón de la verdad o mentira que los sustentan, suscitan polémicas desde hace décadas en los contextos multiculturales y postcoloniales (Tano Palermo 2020). Ello nos hace reflexionar sobre la vigencia de su poder simbólico y la posibilidad de abrir debates. Las imágenes deben interpretarse también como una suma de sustratos culturales. El furor iconoclasta emerge contra el imaginario visual, y alcanza un carácter rotundo con el vandalismo popular.

En ese sentido, existe otro debate pendiente sobre el distanciamiento del monumento con respecto a su legitimidad social en la transmisión de significados. Son 
tiempos turbulentos para "la representación del poder vertical en sentido clásico en favor de concatenaciones transversales, múltiples y heterogéneas"(Scotini 2009: 77). El activismo artístico no quiere apropiarse del poder del Estado como en los años sesenta. Su posición ahora es esquivar sus instituciones (museos, colecciones, monumentos, etc.). La iconoclasia se asume desde el activismo artístico como un deseo popular para intervenir en la transformación social del espacio visual común, olvidando su pasada posición de espectador pasivo. Groys alude a una cuestión básica de los actos iconoclastas: "Para arrancar las imágenes de su entorno normal, para liberarlas de la dominación del significado, hay que ejercer una cierta violencia, lo que supone también un cierto sufrimiento" (2021: 158).

El orden burocrático adormece, impulsa el seguimiento de rutinas bajo las cuales se asegura el control de las circunstancias. La creación y destrucción de imágenes supone tanto la asunción de la tiranía de un régimen escópico como la posibilidad de liberarse de él. Los monumentos participan del desorden visual anticipado en la vida comunitaria, cuando deberían depender del entendimiento social.

La crisis del monumento llega con el enfrentamiento entre los modos visuales dominantes y la visión de los nuevos movimientos sociales. La disensión contemporánea se manifiesta frente a la herencia hegemónica de simbolización unitaria de nuestras sociedades. Con el monumento se alcanzaba en el pasado una suerte de consenso que implicaba una identidad inmediata. A su vez, esa identidad instauraba la armonía entre la estructura política de la comunidad y la naturaleza moral y física de la colectividad. Pero esa armonía desaparece gradualmente en el escenario de la globalización.

En las actuales sociedades pluriculturales es cada vez más notable la demanda de agenciamientos, derivas y reapropiaciones populares de la estructura ideológica de la obra monumental que conecta el espacio público con la violencia de la historia. La mirada sensible sobre las contradicciones de los monumentos inflige una herida a la comunidad. Las conmemoraciones, los compromisos y las negociaciones sobre estas iconografías confieren toda su agraviante temporalidad a esos elementos en el paisaje de las ciudades (Álvarez Hernández 2019). El patrimonio monumental es un modo visual de encarnar una obsesión del tiempo, una regresión de la memoria colectiva, que causa problemas de legibilidad frente a la diversidad cultural de nuestras comunidades.

Al no ser posible en la actualidad diferenciar entre las imágenes en virtud de su capacidad para enseñar u organizar la sociedad, el vandalismo contra el monumento exige una reforma del entorno público urbano, una conservación selectiva y una destrucción embellecedora y crítica de sus elementos artísticos. No fue la condición histórica del monumento la que justificó su permanencia, sino su capacidad para trascender la historia y proporcionar una lección para todo tiempo. Sin embargo, este razonamiento tradicional ha fracasado, pues el contexto físico al que permanecía unido ya no es el espacio particular ideal y su permanencia se considera contraproducente. A esta conclusión llegó el estudio de Savage sobre el monumento al compositor Stephen Foster del siglo XIX en Pittsburgh's Highland Park (Savage 2018: 147).

El monumento construye una nueva poética en el mundo contemporáneo, heredera de la dialéctica romántica entre la permeabilidad de la vida y el arte (Rancière, 2019). Convierte lo normal en excepcional, y lo insólito en ordinario. Y a partir de esta lógica visual organiza cierta clase de política propia. Esta política se afirma sobre una base hermenéutica de símbolos de la historia que es necesario recordar o enseñar.

La crítica contemporánea al monumento puede concebirse como un proceso epistemológico determinado por la racionalización en el intercambio de signos entre la creación artística y los signos de la vida. Dos caminos entrecruzados con la identificación de la consciencia y la inconsciencia, o lo que es lo mismo, la fuerza de las formas (lógos) que busca la expresión a través de la materia, y las turbulencias emocionales del páthos que desordena las formas de la doxa y devuelve al monumento su poder caótico, heterónomo y el hálito de lo no filosófico, lo impensable en el pensamiento. El monumento es una forma política incorrecta a la que la historia actual le niega su autonomía estética.

El monumento, en cuanto compone una totalidad de signos, debe ser pensado, no basta su visibilidad o su representación; el significante, las formas, no puede marcar los límites a la subjetividad. La crisis del monumento es también la crisis de la historia de la subjetividad, y la subjetividad siempre está determinada por una conciencia que es independiente del exterior. El advenimiento de la conciencia histórica es, desde el espíritu hegeliano, un reconocimiento del otro en el mundo exterior y una lucha por superar su alienación. De este modo, la destrucción de las imágenes puede considerarse como una estrategia de superación, no exenta de sufrimiento por la exhibición de las circunstancias en que se produce.

En la crisis del culto al monumento, éste es despojado de su significado original, es desfigurado, profanado, y maltratada su integridad física, de diversas maneras. Es sacrificado en rituales de violenta humillación, expuesto a la mofa pública en un ambiente de crueldad estructural. Las huellas de ese ultraje revelan la materialidad de la imagen como la carne viva de la subjetividad escondida en su interior.

\section{Referencias}

AGENCIAS (2020). "Colón, Cervantes y otras estatuas señaladas por el Black Lives Matter", La Vanguardia, 29 de junio. https://www.lavanguardia.com/historiayvida/edad-moderna/20200629/481955036817/protestas-racismo-eeuu-floyd-estatuas-colon-cervantes-jefferson-davies-colbert-junipero-serra.html 
[Consultado 10-9-2021].

ÁlVAREZ HERNÁNDEZ, A. (2019). “The Other('s) Toronto Public Art: The Challenge of Displaying Canadians'Narratives in a Multicultural/ Diasporic City", RACAR: revue d'art canadienne / Canadian Art Review , 44 (1): 42-53. https://www.jstor.org/stable/26654439 [Consultado 4-11-21].

BELLENTANI, F. y PANICO, M. (2016). “The meanings of monuments and memorials: toward a semiotic approach", Punctum, 2(1): 28-46. http://dx.doi.org/10.18680/hss.2016.0004 [Consultado 10-9-2021].

BELTING, H. (2012). "La idolatría hoy". En Iconoclastia. La ambivalencia de la mirada, Boehm, G. et al. Madrid: La Oficina Ediciones, 77-97.

CONNOR, S. (2002). Cultura Postmoderna. Introducción a las teorías de la contemporaneidad. Madrid: Akal.

CONTRERAS, F. R. y RAMÍREZ ALVARADO, M. (2021). “Estrategias visuales en la protesta activista de movimientos sociales: Eikonoklasmos, furia e imágenes". En International Association for Media and Communication Research - IAMCR, United States International University-Africa, Nairobi, Kenya.

FAUS, J. (2015). "El tiroteo de Charleston en datos. La policía detiene al supuesto autor del ataque, un joven blanco de 21 años identificado como Dylann Roof", El País, 18 de junio. https://elpais. com/elpais/2015/06/18/actualidad/1434637152 677598.html [Consultado 10-9-2021].

FAUS, J. y DE LLANO, P. (2017). “Tres muertos durante la jornada de caos desatada en Charlottesville por una manifestación racista", EI País, 12 de agosto. https://elpais.com/internacional/2017/08/12/ actualidad/1502553163 703843.html [Consultado 10-9-2021].

FREEDBERG, D. (2009). El poder de las imágenes: estudios sobre la historia y la teoría de la respuesta. Madrid: Cátedra.

FREEDBERG, D. (2017). Iconoclasia: historia y psicología de la violencia contra las imágenes. Victoria-Gasteiz: Sans Soeil.

GADDIE, K. y EVANS J. (2021). "A Systems Approach to Understanding Community Power in the Debate over Confederate Monuments", Social Science Quarterly, 102(3): 1128 - 1150. http:// dx.doi.org /10.1111/ssqu.12971 [Consultado 10-9-2021].

GAMBONI, D. (1997.) The destruction of art: iconoclasm and vandalism since the French Revolution. Londres: Reaktion.

GARCÍA MARCO, D. (2016). “¿Dónde está la estatua de Cristóbal Colón que fue juzgada, condenada y colgada el 12 de octubre de 2004 en Caracas?", BBC Mundo Caracas, 12 de octubre. Disponible en: https://www.bbc.com/mundo/noticias-americalatina-37625519 [Consultado 10-9-2021].

GROYS, B. (2021). La lógica de la colección. Barcelona: Arcadia. HERNÁNDEZ-MORA, S. (2021). “Colombia retira las estatuas de Colón e Isabel la Católica", El Mundo, 11 de junio. Disponible en: https://www. elmundo.es/internacional/2021/06/11/60c3970f21efa025498b466a. html [Consultado 10-9-2021]

LAI, T.-H. (2020). "Political vandalism as counter-speech: A defense of defacing and destroying tainted monuments", European Journal of Philosophy, 28(3), 602 - 616. https://doi.org/10.1111/ejop.12573

LIM, C.-M. (2020). "Transforming problematic commemorations through vandalism", Journal of Global Ethics, 16 (3): 414 - 421. http:// dx.doi.org/10.1111/ejop.12573 [Consultado 10-9-2021].

MANETTO, F. y MARCIAL PÉREZ, D. (2021). "La sustitución de la estatua de Colón divide a los expertos: decisión inteligente, desatino o golpe a la memoria", El País, 10 de septiembre. https://elpais.com/ mexico/2021-09-10/la-sustitucion-de-la-estatua-de-colon-divide-alos-expertos-decision-inteligente-desatino-o-golpe-a-la-memoria. html [Consultado 13-9-2021]

MARSCHALL, S. (2017). "Monuments and Affordance: Multisensory Bodily Engagements with the Landscape of Memory in South Africa", Cahiers d'Études Africaines, 52(3): 671-689. http://dx.doi.org/10.4000/ etudesafricaines.20860 [Consultado 10-9-2021].

MIRANDA, D. F. (2020). "Critical commemorations", Journal of Global Ethics, 16(3): 422 - 430. http://dx.doi.org/10.1080/17449626.2021.187 3166 [Consultado 10-9-2021].

MONDZAIN, M.-J. (1996). Image, icône, économie: les sources byzantines de l'imaginaire contemporain. Paris: Le Seuil.

NOGUERA GRACIA, T. (2018). "Iconoclasia: Destrucción del Patrimonio y Narrativa en el Yihadismo", Cadernos de Dereito Actual, 10: 09-27.

NOYES, J. (2018). Política de la iconoclasia, Istor. Revista de historia internacional, 74, 89-100.

PANOFSKY, E. (2004 [1962]). Estudios sobre iconología. 14rd. edn. Madrid: Alianza.

PÉREZ-RAMOS, Y. y RAMIRO-ESTEBAN, D. (2020). "Monumentos confrontados: nuevos roles para el patrimonio ante los desencuentros sociales", Arquitecturas del sur, 38(58): 44-61 http://dx.doi.org/10.22320 107196466.2020.38.058.03 [Consultado 10-9-2021].

RANCIÈRE, J. (2019). Ensayos sobre estética y política. México: Fondo de Cultura Económica.

RÉAU, L. (1994). Histoire du vandalisme : les monuments détruits de l'art français. Paris: Robert Laffont.

REDACCIÓN Y AGENCIAS (2020). “Derrocada la estatua de Edward Colston, comerciante de esclavos del siglo XVII, en Bristol", La Vanguardia, 7 de junio. Disponible en: https://www.lavanguardia.com/ internacional/20200607/481656405395/derrocada-estatua-edwardcolston-comerciante-esclavos-siglo-xvii-bristol-reino-unido.html [Consultado 10-9-2021].

RIEGL, A. (2008 [1903]). El culto moderno a los monumentos. 3rd. edn. Madrid: La Balsa de la Medusa. 
ROS, L. (2020). "La muerte de George Floyd desata protestas contra el racismo y la violencia policial", La Vanguardia. https://www.lavanguardia.com/vida/junior-report/20200608/481662322957/muertegeorge-floyd-desata-protestas-racismo-violencia-policial.html [Consultado 10-9-2021].

SAVAGE, K. (2018). "No Time, No Place: The Existential Crisis of the Public Monument", Future Anterior: Journal of Historic Preservation, History, Theory, and Criticism, 15(2): 147-154. http://dx.doi.org/10.5749/ futuante.15.2.0147 [Consultado 10-9-2021].

SCOTINI, M. (2009). “La imagen constituyente. Representación y poder en la sociedad de control". En Iconoclastia - Iconolatría, Corbeira, D. (ed.). Madrid: Brumaria, 69-80.

SERT, J. L., LÉGER, F. y GIEDION, S. (2015). "Nueve puntos sobre monumentalidad", URBS. Revista de Estudios Urbanos y Ciencias Sociales, 5(2): 197-206. http://www2.ual.es/urbs/index.php/urbs/article/view/ cachorro [Consultado 10-9-2021].

SONEIRA, I. (2020). "Imágenes del peronismo verdadero", Avances del Cesor, 17(23). https://doi.org/10.35305/ac.v17i23.1284 [Consultado 10-9-2021].

STOLLBROCK TRUJILLO, G. (2017). "Representación claroscura: una exploración audiovisual y teórica de la representación del pasado en el cine documental", Íconos. Revista de Ciencias Sociales, 59: 79-102. https://doi.org/10.17141/iconos.59.2017.2678 [Consultado 10-92021].

STROTHER, Z. (2002) ."Iconoclasm by Proxy”. En Iconoclash, Latour, B. and Weibel, P. (eds.). Cambridge MA: MIT Press, 458-459.

STURKEN, M. (1991). "The Wall, the Screen, and the Image: The Vietnam Veterans Memorial", Representations, 35: 118-142. https://doi. org/10.2307/2928719 [Consultado 10-9-2021].

TANO PALERMO, M. (2020). “From Social Deviance to Art: Vandalism, Illicit Dumping, and the Transformation of Matter and Form", Social Sciences, 9(106): 1-15. https://doi.org/10.3390/socsci9060106 [Consultado 10-9-2021].

TRACHANA, A. y ŞERBĂNOIU, I.-G. (2020) ."Violencia, memoria y arquitectura. Las formas de objetivación de la memoria de los acontecimientos violentos del último siglo en el espacio", Arte, Individuo y Sociedad, 32(3): 603-624. https://doi.org/10.5209/aris.63557 [Consultado 10-9-2021].

WATNEY, S. (2015). "Iconoclasms", The Burlington Magazine, 157(1344): 186-189. http://www.jstor.org/stable/24242298 [Consultado 10-9-2021].

\section{Documentos jurídicos}

Parlamento Europeo. Propuesta de Resolución Común presentada de conformidad con el artículo 132, apartados 2 y 4, del Reglamento interno para sustituir a las propuestas de Resolución siguientes: B9-0097/2019 (PPE); B9-0098/2019 (ECR); B9-0099/2019 (S\&D); B9-0100/2019 (Renew) sobre la importancia de la memoria histórica europea para el futuro de Europa (2019/2819(RSP)).

Jefatura del Estado España. Ley 52/2007, de 26 de diciembre, por la que se reconocen y amplían derechos y se establecen medidas en favor de quienes padecieron persecución o violencia durante la Guerra Civil y la Dictadura. BOE núm. 310, de 27/12/2007. Entrada en vigor: 28/12/2007 Departamento: Jefatura del Estado. Referencia: BOE-A-2007-22296. Permalink ELI: https://www.boe.es/eli/es/l/2007/12/26/52/con

\section{Autor/es}

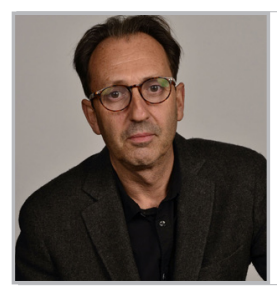

Fernando R. Contreras

fmedina@us.es

Profesor Titular de la Universidad de Sevilla Vicedecano de la Facultad de Comunicación https://orcid.org/0000-0003-1105-5800

Doctor en Filosofía y en Ciencias de la Información y licenciado en Bellas Artes (Diseño y Grabado). Realizó estudios en la licenciatura de Biología, Diseño Industrial y Comunicación Audiovisual. Actualmente es profesor de Cibercultura en el Departamento de Periodismo 1 de la Universidad de Sevilla y de Arte, Tecnología y Comunicación en el Máster de Comunicación y Cultura. Es Vicedecano de la Facultad de Comunicación (12 años) y director del Grupo de Investigación de Tecnología, Arte, Documentación y Comunicación del Plan Andaluz de Investigación (PAIDI HUM868). Ha publicado textos (libros y artículos) sobre Filosofía de la Comunicación, Estudios Visuales, Arte y Teoría de la Cultura. Es autor de "El cibermundo. Dialéctica del discurso informático" (1998), uno de los primeros estudios narrativos en España sobre el videojuego. Su último libro se titula "La desobediencia visual. Estética de los movimientos sociales del siglo XXI" (2021). Es profesor desde hace mas de doce años en LLSH (Faculty of Humanities and Social Sciences, Université Savoie Mont Blanc) con docencia en el Master Création Numérique, en Annecy y en Chámbery (Francia) y durante cuatro años colaborador con el programa de doctorado de la ComUE - Communauté Université Grenoble Alpes. También ha ejercido durante 10 años como director de arte publicitario y ha realizado varias exposiciones de arte.

Artículo enviado el 14/09/2021

Artículo aceptado el 02/11/2021

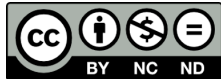

https://doi.org/10.37558/gec.v21i1.1047 